\title{
Systematic Review \\ Diagnostic Considerations for Non-Acanthamoeba Amoebic Keratitis and Clinical Outcomes
}

\author{
Siobhan Moran, Ronnie Mooney * and Fiona L. Henriquez
}

Citation: Moran, S.; Mooney, R.; Henriquez, F.L. Diagnostic Considerations for Non-Acanthamoeba Amoebic Keratitis and Clinical Outcomes. Pathogens 2022, 11, 219. https://doi.org/10.3390/ pathogens11020219

Academic Editors: Fiona Stapleton and Nicole Carnt

Received: 20 January 2022

Accepted: 2 February 2022

Published: 8 February 2022

Publisher's Note: MDPI stays neutral with regard to jurisdictional claims in published maps and institutional affiliations.

Copyright: (C) 2022 by the authors. Licensee MDPI, Basel, Switzerland. This article is an open access article distributed under the terms and conditions of the Creative Commons Attribution (CC BY) license (https:// creativecommons.org/licenses/by/ $4.0 /)$.

\author{
School of Health and Life Sciences, University of West Scotland, Stephenson Place, Glasgow G72 0LH, \\ Lanarkshire, UK; B00265235@studentmail.uws.ac.uk (S.M.); fiona.henriquez@uws.ac.uk (F.L.H.) \\ * Correspondence: ronnie.mooney@uws.ac.uk
}

\begin{abstract}
Cases of amoebic keratitis involving species other than Acanthamoeba are hypothesised to be underdiagnosed and poorly understood. Amoebic keratitis is debilitating and associated with chronic visual impairment. Understanding associated symptoms of non-Acanthamoeba amoebic keratitis could facilitate new diagnostic procedures and enable prompt treatment, ultimately leading to improved patient outcomes. Thus, a review of the literature was undertaken surrounding nonAcanthamoeba amoebic keratitis. Cases were geographically widespread and mostly confined to contact lens wearers $\leq 30$ years old exposed to contaminated water sources and/or demonstrating poor lens hygiene. Vermamoeba vermiformis (previously Hartmanella vermiformis) was the most common causative agent, and a moderate number of mixed keratitis cases were also reported. A crucial disease indicator was early onset stromal deterioration/ulcerations, reported in 10 of the studies, usually only occurring in advanced Acanthamoeba keratitis. Mixed infections were the most difficult to treat, often requiring keratoplasty after unsuccessful combination treatment regimens. New diagnostic measures for non-Acanthamoeba amoebic keratitis should consider early onset stromal disease as a key disease indicator. Deep corneal scrapes are also necessary for accurate amoebic identification. Moreover, a combination approach to diagnosis is advised and should involve culture, microscopy and PCR techniques. In vitro drug sensitivity tests should also be conducted to help develop patient-specific treatment regimes.
\end{abstract}

Keywords: keratitis; amoeba; hartmannella; acanthamoeba; vannella; vahlkampfia; vermamoeba; diagnosis; pathogenesis

\section{Introduction}

Amoebic keratitis is of growing clinical concern given the recent rise in cases globally and the difficulties associated with accurate diagnosis and treatment [1]. A recent outbreak of amoebic keratitis has been described in the UK, with other developed countries following similar trends [1-5]. Acanthamoeba spp. are most commonly associated with amoebic keratitis, and most cases can be linked to contact lens wear and poor contact lens hygiene [6-8]. Although not the only risk pathways of infection, exposure of contact lenses to contaminated water, overwearing lenses and improper cleaning and storage of lenses and cases (e.g., using tap water for cleaning purposes) enable amoebic adhesion and growth on lens surfaces and subsequently increase the risk of corneal infection [7].

While Acanthamoeba keratitis is the most common form of amoebic keratitis and as such has been the subject of extensive research, there are other potential contributing organisms that are less considered [1]. Despite a lack of conclusive evidence demonstrating that amoebae, with the exception of Acanthamoeba, are capable of causing keratitis in isolation, there have been several reported cases of positively identified non-Acanthamoeba amoeba species during keratitis infections documented in the literature. For example, Vermamoeba vermiformis (previously Hartmannella vermiformis), Vannella and Vahlkampfia species have all been associated with amoebic keratitis, and a lack of knowledge surrounding their potential for infections may hinder effective diagnostic or treatment protocols [9]. 
Because of the poorly understood role of non-Acanthamoeba amoebic keratitis, we have conducted an extensive review of the literature to further detail its prevalence, diagnoses, disease symptoms and treatments. In doing this, we aim to further the accuracy of diagnostic procedures that might aid in the rapid diagnosis and treatment of these pathogens.

\section{Results}

A total of 18 articles satisfied the inclusion guidelines set for this review (Figure 1), and key information was extracted from each article (Table 1). Studies were conducted in various locations worldwide, and study participants were diverse with respect to gender, age and history of contact lens wear (Table 2). Of all the identified case studies, participant specifics were only detailed in the study conducted by Hajialilo et al. [10]; consequently, they are excluded from Table 2's participant section. Cases were described more frequently in females with $61.5 \%$ (8 female to 5 male) and also more frequent in participants within the 30 -and-under age category $(69.2 \%$ of cases, $9 \leq 30 \mathrm{y} / \mathrm{o}$ to $4>30 \mathrm{y} / \mathrm{o})$. Cases were much more apparent in contact lens wearers than in non-contact lens wearers, with $92 \%$ of cases linked to contact lens wear (61 to 5).
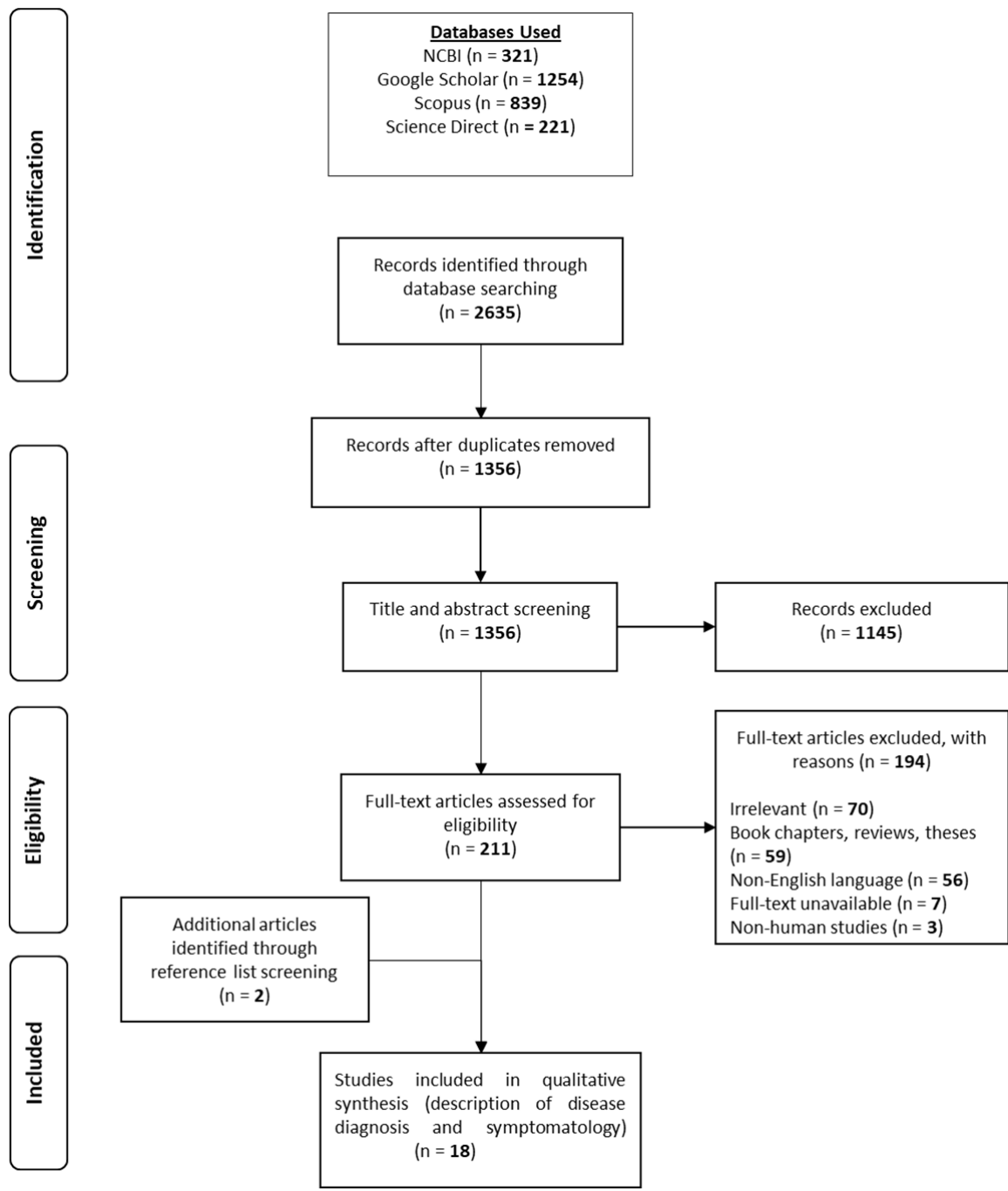

Figure 1. PRISMA flow diagram. 
Table 1. Suspected or confirmed cases of non-Acanthamoeba amoebic keratitis (1995-2019).

\begin{tabular}{|c|c|c|c|c|c|c|}
\hline $\begin{array}{c}\text { First Author, Year and } \\
\text { Journal }\end{array}$ & $\begin{array}{c}\text { Study Type and } \\
\text { Location }\end{array}$ & Patient Information and Research Aim & Clinical Manifestations & $\begin{array}{c}\text { Laboratory } \\
\text { Investigation(s) }\end{array}$ & Findings & Treatment \\
\hline $\begin{array}{l}\text { Kennedy et al. (1995) } \\
\text { The lancet [11] }\end{array}$ & CR (Ireland) & $\begin{array}{l}\text { Analysing causative agent(s) of keratitis } \\
\text { in a 17-year-old F soft } C L \text { wearer }\end{array}$ & Corneal erosion and stromal ring infiltration & $\begin{array}{l}\text { Corneal scrapes: culture } \\
\text { and microscopy }\end{array}$ & $\begin{array}{l}\text { Vermamoeba detected (in } \\
\text { isolation) }\end{array}$ & Polyhexamethylene \\
\hline $\begin{array}{l}\text { Aitken et al. (1996) } \\
\text { Ophthalmol [12] }\end{array}$ & CR (UK) & $\begin{array}{l}\text { Analysing causative agent(s) of keratitis } \\
\text { in a 21-year-old M soft CL wearer }\end{array}$ & $\begin{array}{l}\text { Eye pain, watery discharge, corneal lesion, } \\
\text { inflammation, epithelial defect, oedema, } \\
\text { decreased visual acuity, photophobia, keratic } \\
\text { precipitates and endothelial damage }\end{array}$ & $\begin{array}{l}\text { Corneal scrapes and } \\
\text { corneal biopsy: culture } \\
\text { and microscopy }\end{array}$ & $\begin{array}{l}\text { Vermamoeba and Vahlkampfia } \\
\text { detected }\end{array}$ & $\begin{array}{c}\text { Propamidine isethionate, } \\
\text { neomycin sulfate, } \\
\text { prednisolone, atropine and } \\
\text { keratoplasty }\end{array}$ \\
\hline $\begin{array}{l}\text { Inoue et al. (1998) } \\
\text { American Journal of } \\
\text { Ophthalmol [13] }\end{array}$ & CR (Japan) & $\begin{array}{l}\text { Analysing causative agent(s) of keratitis } \\
\text { in a 54-year-old F hard CL wearer }\end{array}$ & $\begin{array}{l}\text { Eye pain, foreign body sensation, stromal ring } \\
\text { infiltration, stromal ulcer, corneal lesion, impaired } \\
\text { vision, epithelial defect, photophobia and anterior } \\
\text { chamber inflammation }\end{array}$ & $\begin{array}{l}\text { Corneal scrapes: culture } \\
\text { and microscopy }\end{array}$ & $\begin{array}{l}\text { Acanthamoeba and Vermamoeba } \\
\text { detected }\end{array}$ & $\begin{array}{l}\text { miconazole, fluconazole, } \\
\text { natamycin, ofloxacin and } \\
\text { keratoplasty }\end{array}$ \\
\hline $\begin{array}{l}\text { Aimard et al. (1998) } \\
\text { Clinical Infectious } \\
\text { Diseases [14] }\end{array}$ & CR (France) & $\begin{array}{l}\text { Analysing causative agent(s) of keratitis } \\
\text { in a } 40 \text {-year-old F CL wearer }\end{array}$ & $\begin{array}{l}\text { Stromal involvement observed and symptoms } \\
\text { described as "typical of Acanthamoeba" }\end{array}$ & $\begin{array}{l}\text { Corneal scrapes and } \\
\text { corneal biopsy: culture } \\
\text { and microscopy }\end{array}$ & $\begin{array}{c}\text { Acanthamoeba and Vermamoeba } \\
\text { detected }\end{array}$ & $\begin{array}{l}\text { Neomycin, polymyxin, } \\
\text { fluconazole, hexamidine, } \\
\text { propamidine and } \\
\text { keratoplasty }\end{array}$ \\
\hline $\begin{array}{l}\text { Alexandrakis et al. (1998) } \\
\text { Arch Ophthalmol [15] }\end{array}$ & CR (USA) & $\begin{array}{l}\text { Analysing causative agent(s) of keratitis } \\
\text { in a 30-year-old M non-CL wearer who } \\
\text { incurred ocular trauma }\end{array}$ & $\begin{array}{l}\text { Severe ocular pain, irritation, stromal infiltrates, } \\
\text { corneal oedema, epithelial } \\
\text { defect and inflammation }\end{array}$ & $\begin{array}{l}\text { Corneal scrapes: culture } \\
\text { and microscopy }\end{array}$ & $\begin{array}{l}\text { Vahlkampfia detected } \\
\text { (in isolation) }\end{array}$ & $\begin{array}{l}\text { Propamidine, } \\
\text { polyhexamethylene, } \\
\text { neomycin, polymyxin, } \\
\text { bacitracin zinc and } \\
\text { Clotrimazole }\end{array}$ \\
\hline $\begin{array}{l}\text { Bennett et al. (1998) } \\
\text { The British Journal of } \\
\text { Ophthalmol [16] }\end{array}$ & CS (UK) & $\begin{array}{l}\text { Analysing causative agents of keratitis in } \\
\text { a small cohort ( } 24 \mathrm{M} \text { and } 31 \mathrm{~F} \text { patients } \\
\text { with presumed microbial keratitis) }\end{array}$ & Central or peripheral infiltrates & $\begin{array}{l}\text { Corneal scrapes: culture } \\
\text { and microscopy }\end{array}$ & $\begin{array}{l}1 \text { Vahlkampfia positive case } \\
\text { (detected in isolation in CL } \\
\text { wearer) }\end{array}$ & $\begin{array}{l}\text { Gentamicin and } \\
\text { Cefuroxime }\end{array}$ \\
\hline $\begin{array}{l}\text { Michel et al. (2000) } \\
\text { Parasitology Resources [17] }\end{array}$ & CR (Germany) & $\begin{array}{l}\text { Analysing causative agent(s) of keratitis } \\
\text { in a 24-year-old F CL wearer }\end{array}$ & $\begin{array}{l}\text { Pain, photophobia, reduced visual acuity, } \\
\text { inflammation, corneal ulcer, conjunctival } \\
\text { hyperaemia and central ring infiltrate }\end{array}$ & $\begin{array}{l}\text { Corneal and CL swabs: } \\
\text { culture and microscopy }\end{array}$ & $\begin{array}{l}\text { P. aeruginosa, Vermamoeba and } \\
\text { two Vannella sp. detected }\end{array}$ & $\begin{array}{l}\text { Gentamicin, cefazolin, } \\
\text { propamidine, artificial } \\
\text { tears and keratoplasty }\end{array}$ \\
\hline $\begin{array}{c}\text { Scheid (2007) } \\
\text { Parasitology Resources [18] }\end{array}$ & CR (Germany) & $\begin{array}{l}\text { Analysing causative agent(s) of keratitis } \\
\text { in a 24-year-old F CL wearer }\end{array}$ & $\begin{array}{l}\text { Inflammation, impaired vision, photophobia, } \\
\text { central ring infiltrate and severe pain }\end{array}$ & $\begin{array}{l}\text { Corneal and CL swabs: } \\
\text { culture and microscopy }\end{array}$ & $\begin{array}{l}\text { P. aeruginosa, Vermamoeba and } \\
\text { two Vannella sp. detected }\end{array}$ & $\begin{array}{l}\text { Gentamicin, cefazolin, } \\
\text { propamidine artificial tears } \\
\text { and keratoplasty }\end{array}$ \\
\hline $\begin{array}{l}\text { Lorenzo-Morales et al. } \\
\text { (2007) } \\
\text { Parasitology Resources [19] }\end{array}$ & CR (Spain) & $\begin{array}{l}\text { Analysing causative agent(s) of keratitis } \\
\text { in a 21-year-old M soft CL wearer }\end{array}$ & $\begin{array}{l}\text { Severe pain, reduced visual acuity, photophobia, } \\
\text { inflammation and stromal keratitis }\end{array}$ & $\begin{array}{l}\text { Corneal scrapes: culture } \\
\text { and microscopy; PCR tests }\end{array}$ & $\begin{array}{c}\text { Acanthamoeba and Vermamoeba } \\
\text { detected }\end{array}$ & $\begin{array}{l}\text { Tobramycin, Propamidine, } \\
\text { povidone-iodine, } \\
\text { diclofenac and ofloxacin }\end{array}$ \\
\hline $\begin{array}{l}\text { Yera et al. (2008) } \\
\text { The British Journal of } \\
\text { Ophthalmol [20] }\end{array}$ & CS (France) & $\begin{array}{l}\text { Analysing causative agent(s) of keratitis } \\
\text { in a small cohort ( } 37 \mathrm{M} \text { and F patients } \\
\text { with suspected AK). All CL wearers }\end{array}$ & Pain and stromal ring infiltrates & $\begin{array}{l}\text { Corneal scrapes: culture } \\
\text { and microscopy; CL and } \\
\text { CL case investigations; } \\
\text { PCR tests }\end{array}$ & $\begin{array}{l}1 \text { Vermamoeba positive case } \\
\text { (detected in isolation) } \\
1 \text { Vahlkampfia positive case } \\
\text { (detected in isolation) }\end{array}$ & Unexplained \\
\hline $\begin{array}{l}\text { Ozkoc et al. (2008) } \\
\text { Journal of Medical } \\
\text { Microbiology [21] }\end{array}$ & CR (Turkey) & $\begin{array}{l}\text { Analysing causative agent(s) of keratitis } \\
\text { in a 61-year-old M non-CL wearer who } \\
\text { incurred ocular trauma }\end{array}$ & $\begin{array}{l}\text { Irritation, pain, redness, reduced visual acuity, } \\
\text { corneal oedema, epithelial defect and epithelial } \\
\text { erosions }\end{array}$ & $\begin{array}{l}\text { Corneal scrapes: culture } \\
\text { and microscopy; PCR tests }\end{array}$ & $\begin{array}{l}\text { Paravahlkampfia and herpes } \\
\text { simplex virus detected }\end{array}$ & $\begin{array}{l}\text { Acyclovir, propamidine } \\
\text { and polyhexamethylene }\end{array}$ \\
\hline
\end{tabular}


Table 1. Cont.

\begin{tabular}{|c|c|c|c|c|c|c|}
\hline $\begin{array}{c}\text { First Author, Year and } \\
\text { Journal }\end{array}$ & $\begin{array}{c}\text { Study Type and } \\
\text { Location }\end{array}$ & Patient Information and Research Aim & Clinical Manifestations & $\begin{array}{c}\text { Laboratory } \\
\text { Investigation(s) }\end{array}$ & Findings & Treatment \\
\hline $\begin{array}{l}\text { Niyyati et al. (2010) } \\
\text { Experimental } \\
\text { Parasitology [22] }\end{array}$ & CR (Iran) & $\begin{array}{l}\text { Analysing causative agent(s) of keratitis } \\
\text { in a 35-year-old F soft CL wearer }\end{array}$ & $\begin{array}{l}\text { Severe pain, redness, irritation, ulceration, } \\
\text { photophobia and opacity in the left eye }\end{array}$ & $\begin{array}{l}\text { Corneal scrapes: culture } \\
\text { and microscopy; PCR tests; } \\
\text { CL and CL case } \\
\text { investigations }\end{array}$ & $\begin{array}{c}\text { Acanthamoeba and Vahlkampfia } \\
\text { detected }\end{array}$ & $\begin{array}{l}\text { Propamidine and } \\
\text { keratoplasty }\end{array}$ \\
\hline $\begin{array}{l}\text { Mattana et al. (2012) } \\
\text { Mappe Parassitologiche [23] }\end{array}$ & CS (Italy) & $\begin{array}{l}\text { Analysing causative agent(s) of keratitis } \\
\text { in a small cohort with suspected early } \\
\text { stage Acanthamoeba keratitis }\end{array}$ & $\begin{array}{c}\text { Diffuse punctate epitheliopathy and/or epithelial } \\
\text { lesions }\end{array}$ & $\begin{array}{l}\text { Corneal scrapes: culture } \\
\text { and microscopy; PCR tests }\end{array}$ & $\begin{array}{l}1 \text { mixed case of Vermamoeba and } \\
\text { Vahlkampfia, } 7 \text { positive } \\
\text { Vermamoeba cases (detected in } \\
\text { isolation) (all CL wearers) }\end{array}$ & $\begin{array}{l}\text { Propamidine and } \\
\text { polyhexanide }\end{array}$ \\
\hline $\begin{array}{l}\text { Arnalich-Montiel } \\
\text { et al. (2013) } \\
\text { Cornea [24] }\end{array}$ & CS (Spain) & $\begin{array}{l}\text { Analysing causative agent(s) of keratitis } \\
\text { in a small cohort with suspected AK (5 F } \\
\text { and } 2 \text { M patients) }\end{array}$ & $\begin{array}{l}\text { Subepithelial changes, ulceration, ring infiltrates } \\
\text { and stromal keratitis }\end{array}$ & $\begin{array}{l}\text { Epitheliectomy and } \\
\text { corneal scrapes: culture } \\
\text { and microscopy; PCR tests }\end{array}$ & $\begin{array}{l}2 \text { cases of mixed keratitis with } \\
\text { Acanthamoeba and Vahlkampfia } \\
\text { (both CL wearers) }\end{array}$ & $\begin{array}{c}\text { Chlorhexidine, } \\
\text { Propamidine, } \\
\text { polyhexamethylene } \\
\text { voriconazole and amniotic } \\
\text { membrane transplant }\end{array}$ \\
\hline $\begin{array}{l}\text { Abedkhojasteh et al. (2013) } \\
\text { Iranian Journal of } \\
\text { Parasitology [9] }\end{array}$ & CR (Iran) & $\begin{array}{l}\text { Analysing causative agent(s) of keratitis } \\
\text { in a 22-year-old F soft CL wearer }\end{array}$ & $\begin{array}{l}\text { Eye pain, photophobia, blurred vision, redness, } \\
\text { tearing, foreign body sensation, opacity in } \\
\text { epithelium and stroma }\end{array}$ & $\begin{array}{l}\text { Culture and microscopy } \\
\text { with CL, storage case and } \\
\text { cleaning solutions; PCR } \\
\text { tests }\end{array}$ & $\begin{array}{l}\text { Vermamoeba detected (in } \\
\text { isolation) }\end{array}$ & Polyhexamethylene \\
\hline $\begin{array}{l}\text { Hajialilo et al. (2015) } \\
\text { Iranian Journal of } \\
\text { Parasitology [10] }\end{array}$ & CS (Iran) & $\begin{array}{c}\text { Analysing causative agent(s) of keratitis } \\
\text { in a 23-year-old M and 21-year-old F soft } \\
\text { CL wearers }\end{array}$ & $\begin{array}{l}\text { Foreign body sensation, eye pain, photophobia, } \\
\text { redness, tearing, burning, blurred vision and } \\
\text { impaired vision }\end{array}$ & $\begin{array}{l}\text { Culture and microscopy } \\
\text { with CL and associating } \\
\text { paraphernalia; PCR tests }\end{array}$ & $\begin{array}{l}1 \text { mixed case of Acanthamoeba } \\
\text { and Vermamoeba, } 1 \text { Vermamoeba } \\
\text { positive case (in isolation) }\end{array}$ & Polyhexamethylene \\
\hline $\begin{array}{l}\text { Tolba et al. (2016) PLOS } \\
\text { Neglected Tropical } \\
\text { Diseases [25] }\end{array}$ & CR (Egypt) & $\begin{array}{l}\text { Analysing causative agent(s) of keratitis } \\
\text { in an Egyptian patient who incurred } \\
\text { ocular trauma }\end{array}$ & Unexplained & $\begin{array}{l}\text { Corneal scrapes: culture } \\
\text { and microscopy; PCR tests }\end{array}$ & $\begin{array}{l}\text { Allovahlkampfia spelaea detected } \\
\text { (in isolation) }\end{array}$ & Unexplained \\
\hline $\begin{array}{l}\text { Pinna et al. (2017) } \\
\text { Cornea [26] }\end{array}$ & CS (Italy) & $\begin{array}{l}\text { Analysing causative agents of keratitis in } \\
\text { a small cohort ( } 43 \mathrm{M} \text { and F patients with } \\
\text { suspected keratitis) } 95 \% \text { CL wearers }\end{array}$ & $\begin{array}{l}\text { Corneal inflammation, keratoneuritis, epithelial } \\
\text { defects and haze, pseudodendrites, ring infiltrates, } \\
\text { inflammation and limbitis }\end{array}$ & $\begin{array}{l}\text { Corneal scrapes: culture } \\
\text { and microscopy; PCR tests }\end{array}$ & $\begin{array}{c}24 \text { Vermamoeba positive cases } \\
\text { detected (in isolation), } \\
12 \text { Vahlkampfia positive cases (in } \\
\text { isolation), } \\
3 \text { mixed cases of Vermamoeba } \\
\text { and Vahlkampfia }\end{array}$ & $\begin{array}{l}\text { Polyhexamethylene } \\
\text { (5 patients with advanced } \\
\text { keratitis showed chronic } \\
\text { visual impairment, likely } \\
\text { requiring keratoplasty) }\end{array}$ \\
\hline
\end{tabular}

CR—Case Report, CS-Case Series, CL—contact lens(es), F-female, M-male, PCR—polymerase chain reaction, AK-Acanthamoeba keratitis. 
Table 2. Summary of study characteristics.

\begin{tabular}{|c|c|}
\hline \multicolumn{2}{|c|}{ Study Type $(\mathrm{n}=18)$} \\
\hline CR & 12 \\
\hline CS & 6 \\
\hline \multicolumn{2}{|c|}{ Publication Dates $(\mathrm{n}=18)$} \\
\hline 1995-2009 & 11 \\
\hline 2010-2019 & 7 \\
\hline \multicolumn{2}{|c|}{ Location $(n=18)$} \\
\hline UK & 2 \\
\hline Ireland & 1 \\
\hline USA & 1 \\
\hline France & 2 \\
\hline Japan & 1 \\
\hline Germany & 2 \\
\hline Spain & 2 \\
\hline Turkey & 1 \\
\hline Iran & 3 \\
\hline Italy & 2 \\
\hline Egypt & 1 \\
\hline \multicolumn{2}{|c|}{ Participants $(n=20)$} \\
\hline Females $\leq 30$ years old & 5 \\
\hline Females $>30$ years old & 3 \\
\hline Males $\leq 30$ years old & 4 \\
\hline Males $>30$ years old & 1 \\
\hline CR unknown gender and age & 1 \\
\hline${ }^{1}$ Case series & 6 \\
\hline \multicolumn{2}{|c|}{${ }^{2}$ CL history $(n=66)$} \\
\hline CL wearer & 61 \\
\hline Non-CL wearer & 5 \\
\hline
\end{tabular}

${ }^{1}$ gender- and age-related information absent (excluding study by Hajialilo et al. [10]; this information has been recorded). ${ }^{2}$ includes information from CRs and all CS, as CL history of amoebic keratitis positive cases was discussed.

Of all infections, $21 \%$ were identified in conjunction with an additional amoebic infection, with half being a co-infection with an Acanthamoeba spp. Isolated infections with Vermamoeba vermiformis were most frequent, followed by isolated Vahlkampfia infections ( $53 \%$ and $23 \%$, respectively). It should also be noted that in many cases, non-amoebic co-infective agents were identified during diagnoses, and in others, evidence of extensive screening to exclude the presence of additional microbial or viral pathogens was not provided. Thus, the role of these amoebae as causative agents of keratitis and not as vectors for the transmission of other microbial pathogens, as has been described in other free-living amoebae [27], remains inconclusive. Nonetheless, the most common clinical manifestations of non-Acanthamoeba amoebic keratitis included pain (61\% of studies), inflammation and irritation (61\%), stromal keratitis and ulcerations (56\%), epithelial abnormalities (50\%), ring infiltrates (50\%), impaired vision (44\%) and photophobia (44\%) (Table 3). 
Table 3. Amoebic keratitis causative agents and symptoms described across all studies.

\begin{tabular}{cc}
\hline Amoebae sp. Detected & Percent of Cases (n = 66) \\
\hline Vermamoeba & $53 \%$ \\
Vahlkampfia & $23 \%$ \\
Vermamoeba and Vahlkampfia & $7.5 \%$ \\
Acanthamoeba and Vermamoeba & $6 \%$ \\
Acanthamoeba and Vahlkampfia & $4.5 \%$ \\
Vermamoeba and Vannella & $3 \%$ \\
Paravahlkampfia & $1.5 \%$ \\
Allovahlkampfia & $1.5 \%$ \\
\hline Symptoms & Percent of Studies (n= 18) \\
\hline Pain & $61 \%$ \\
Inflammation, irritation and redness & $61 \%$ \\
Stromal keratitis and ulcerations & $56 \%$ \\
Ring infiltrates & $50 \%$ \\
Impaired vision & $50 \%$ \\
Photophobia & $44 \%$ \\
Foreign body sensation & $44 \%$ \\
Oedema & $17 \%$ \\
Oppacity & $17 \%$ \\
Burning/stinging & $11 \%$ \\
Discharge & $6 \%$ \\
Keratoneuritis & $6 \%$ \\
Pseudodendrites & $6 \%$ \\
\hline & $6 \%$ \\
\hline
\end{tabular}

Diagnostic techniques vary between studies, with earlier studies relying primarily on culture and microscopy techniques to identify suspected pathogens. More recent diagnoses, however, have involved the use of $18 \mathrm{~s}$ rRNA sequencing techniques to provide more accurate diagnoses with genus-specific primers (Figure 2). Additionally, temperature tolerance tests have been performed, as they are deemed to be good indicators of pathogenic virulence $[26,28]$.

Therapeutic approaches were broad and predominantly included drug combinations for all forms of amoebic keratitis (Table 1). This approach is similar to the approach taken with AK because no single anti-amoebic agent exists that can successfully eradicate all Acanthamoeba genotypes; hence, drug combinations are used [7,29]. Medical interventions included anti-amoebic agents (topical biguanides and aromatic diamidines), antibiotics, antifungals, antivirals and anti-inflammatory medications. Notably, several studies reported the need for keratoplasty due to poor treatment responses (Table 1) [12-14,17,18,22,24,26]. This emphasises the difficulty of finding an effective therapeutic agent to cure amoebic keratitis and highlights the possibility of drug resistance in other FLA besides Acanthamoeba. 


\section{Clinical Assessment}

Suspected amoebic keratitis:

- History of CL use

- $\quad$ Recent contact with contaminated water source(s) and/or poor CL hygiene

- Clinical signs of amoebic keratitis and description of common symptoms (earlyonset stromal keratitis and ulcerations are indicative of Vahlkampfia, Vermamoeba and Vannella sp. involvement)

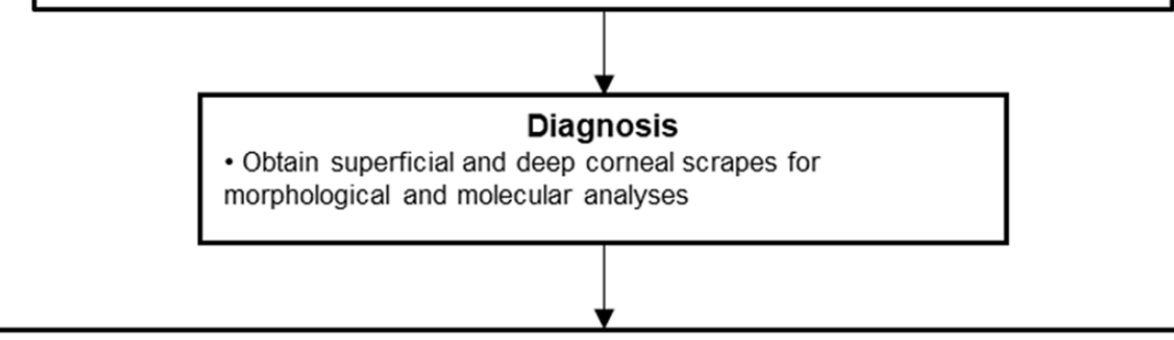

\section{Culture \& Microscopy}

- Culture sample on NNA (1-2\%) seeded with heat inactivated Escherichia colior Enterobacter cloacae for microscopy analysis:

Acanthamoeba - large trophozoites, translucent and "blob-like". Multiple pseudopodia Prominent contractile vacuole \& nucleus

Vermamoeba - cylindric, medium-sized trophozoites. Single pseudopodia and monopodial locomotion. Prominent contractile vacuole and nucleus.

Vahlkampfia - pleiomorphic, but usually cylindric, medium-sized trophozoites with flat structure. Single pseudopodia and eruptive locomotion. Prominent contractile vacuole and nucleus.

Vannella sp. - large, fan-shaped trophozoites. Flattened structure. Multiple pseudopodia Prominent nucleus and contractile vacuole.

Drug sensitivity and temperature tolerance -Perform drug sensitivity tests to determine most efficient treatment regime Can perform additional cytotoxicity and temperature tolerance tests on subcultures to analyse pathogenicity

-Temperature tolerance tests:

Acanthamoeba - Growth at $37^{\circ} \mathrm{C}$

Vermamoeba - Growth at $37^{\circ} \mathrm{C}$

Vahlkampfia - Growth at $37^{\circ} \mathrm{C}$

Paravahlkampfia - Growth at $35^{\circ} \mathrm{C}$

\section{PCR Investigations}

- Perform PCR tests with multiple primer pairs for enhanced FLA species detection

- Genetic sequencing and genotyping for all amoebic

sp. identified (using GenBank database)

JDP primer pairs for Acanthamoeba

F: 5'-GGCCCAGATCGTTTACCGTGAA-3',

R: 5'-TCTCACAAGCTGCTAGGGGAGTCA-3'

JITS primer pairs for Vahlkampfia

F: 5'-GAACCTGCGTAGGGATCATTT-3',

R: 5'-TाTCTTTCCTCCCCTTATTA-3'

NA primer pairs for Vermamoeba \& Vannella:

F: 5' GCTCCAATAGCGTATATTAA-3'

R: 5'-AGAAAGAGCTATCAATCTGT-3'

Figure 2. Diagnostic flowchart for non-Acanthamoeba amoebic keratitis. Stromal involvement is a key disease indicator. Deep corneal scrapes can facilitate non-Acanthamoeba amoebic detection, and the use of multiple primer pairs can aid detection of multi-amoeba sp. in a sample. 


\section{Discussion}

This review demonstrates that cases of non-Acanthamoeba amoebic keratitis are occurring and are geographically widespread; no single location showed a significantly higher incidence rate than any other (Table 2). Notably, however, disease incidence appears to be confined to developed countries, thus following a similar pattern to AK occurrences [7]. Although it is unclear, this might be the result of differences in diagnostic techniques between countries. In terms of patient demographics, Table 2 shows that the majority of individuals diagnosed with non-Acanthamoeba amoebic keratitis were $\leq 30$ years old, and a significantly high proportion of positive cases were associated with contact lens wearers (61 cases vs. 5 non-CL wearers who had suffered ocular trauma). These findings also coincide with typical AK observations in which amoebic keratitis predominantly occurs in young, economically active adults who are most likely to wear contact lenses [2,7].

The similarities to AK infections complicate diagnoses. Generally, treatment outcomes of AK infections coincide with the speed by which accurate diagnoses can be made [7,30]; thus, a similar emphasis should be placed on rapid diagnosis in non-Acanthamoeba amoebic keratitis. Differentiation between amoebic infections is difficult; despite this, early onset stromal keratitis and ulcerations are indicative of Vahlkampfia, Vermamoeba and Vannella sp. involvement and could be useful during early observations (see Table 1) $[9,11,13-15,17,19,20,22,24]$. While microscopic and culture techniques can be applied during diagnostics, species identification using PCR tests remains the most accurate strategy for diagnosis and should be utilised at the earliest possible convenience [1]. We provide a more comprehensive diagnostic workflow for suspected amoebic keratitis in Figure 2. The presence of co-infectious agents in amoebic keratitis is common, and several non-amoebic species were also identified that can complicate treatment, diagnosis and the overall understanding of amoebic influence during infections [11,12,17,18]. For example, Kennedy et al. (1995) [11] reported growth of Staphylococcus aureus from corneal swabs, while Aitken et al. (1996) [12] noted the presence of yeast-like fungi on the corneal surface of the patient. Advances in molecular techniques allow more comprehensive screening for co-infectious agents and should be conducted in tandem with a traditional culture-based approach to assess the most appropriate course of action for the patient.

Despite the rarity of non-Acanthamoeba amoebic keratitis, the literature compiled within this review demonstrates that care must be applied during the initial diagnoses of amoebic keratitis to ensure the most suitable treatment method is applied. It is also worth noting the recent rise in AK infections globally [2-5] and that consideration must also be given as to whether non-Acanthamoeba causative agents of amoebic keratitis follow a similar trend. Overall, we demonstrate here that non-Acanthamoeba amoebic keratitis follows a similar pattern with regard to patient demographics and treatment regimens and that infections generally coincide with contact lens wear. We also highlight differences in disease presentation and methods of diagnoses. Despite its low prevalence, a broadspectrum approach should be applied to the initial treatment of amoebic keratitis, which will necessitate further investigation into how AK therapies interact with other causative agents of amoebic keratitis. Furthermore, the role of non-Acanthamoeba amoebic species in keratitis infections has yet to be fully elucidated and, therefore, warrants additional research.

\section{Materials and Methods}

Four key databases were accessed: Scopus, Science Direct, Google Scholar and The National Center for Biotechnology Information (NCBI). The search criteria narrowly focused on Vahlkampfia, Vermamoeba (Hartmannella) and Vannella sp. and their involvement in keratitis. No date restrictions were applied due to the elusive nature of non-Acanthamoeba amoebic infections and the scarcity of relevant literature. Key words combined with Boolean operators and nested search strings were used to ensure results were confined to the topic of interest. Figure 1 details the flow path by which studies of non-Acanthamoeba amoebic keratitis infections were identified. All reported cases of keratitis associated 
with Vahlkampfia and Vermamoeba vermiformis (Hartmannella), coupled with descriptions of symptomatology and diagnostic measures, were included in this review. No restrictions to publication date, country, patient gender, race or age were applied. Studies selected for inclusion in this review were analysed against a Scottish Intercollegiate Guidelines Network flowchart [31], as recommended by the University of Strathclyde [32], to accurately determine study type. All studies were established to be case reports (CR) or case series (CS). Thereafter, each paper was quality-assessed against two critical appraisal tools provided by The Joanna Briggs Institute [33] and the Centre for Evidence-Based Management [34]. Data were presented as both total counts and percentages of overall data.

Author Contributions: R.M. designed the structure of the review article, critically reviewed and contributed to the manuscript; S.M. conducted the review of the literature and data analysis and contributed to the manuscript; F.L.H. conceived and designed the review article, critically reviewed the manuscript and coordinated the activities of co-authors. All authors have read and agreed to the published version of the manuscript.

Funding: This research received no external funding.

Institutional Review Board Statement: Not applicable.

Informed Consent Statement: Not applicable.

Data Availability Statement: Not applicable.

Conflicts of Interest: The authors declare no conflict of interest.

\section{References}

1. Lorenzo-Morales, J.; Khan, N.A.; Walochnik, J. An update on Acanthamoeba keratitis: Diagnosis, pathogenesis and treatment. Parasite 2015, 22, 10. [CrossRef] [PubMed]

2. Carnt, N.; Hoffman, J.J.; Verma, S.; Hau, S.; Radford, C.F.; Minassian, D.C.; Dart, J.K.G. Acanthamoeba keratitis: Confirmation of the UK outbreak and a prospective case-control study identifying contributing risk factors. Br. J. Ophthalmol. 2018, 102, 1621-1628. [CrossRef] [PubMed]

3. Randag, A.C.; Van Rooij, J.; Van Goor, A.T.; Verkerk, S.; Wisse, R.P.; Saelens, I.E.; Stoutenbeek, R.; van Dooren, B.T.; Cheng, Y.Y.; Eggink, C.A. The rising incidence of Acanthamoeba keratitis: A 7-year nationwide survey and clinical assessment of risk factors and functional outcomes. PLOS ONE 2019, 14, e0222092. [CrossRef]

4. Höllhumer, R.; Keay, L.; Watson, S.L. Acanthamoeba keratitis in Australia: Demographics, associated factors, presentation and outcomes: A 15-year case review. Eye 2020, 34, 725-732. [CrossRef] [PubMed]

5. Scruggs, B.A.; Quist, T.S.; Salinas, J.L.; Greiner, M.A. Acanthamoeba keratitis cases-Iowa, 2002-2017. Morb. Mortal Wkly. Rep. 2019, 68, 448-449. [CrossRef]

6. Rocha-Azevedo, B.D.; Tanowitz, H.B.; Marciano-Cabral, F. Diagnosis of Infections Caused by Pathogenic Free-Living Amoe-bae. Interdiscip. Perspect. Infect. Dis. 2009, 2009, 251406. [PubMed]

7. de Lacerda, A.G.; Lira, M. Acanthamoeba keratitis: A review of biology, pathophysiology and epidemiology. Ophthalmic Physiol. Opt. 2020, 41, 116-129. [CrossRef]

8. Fanselow, N.; Sirajuddin, N.; Yin, X.T.; Huang, A.J.; Stuart, P.M. Acanthamoeba Keratitis, Pathology, Diagnosis and Treatment. Pathology 2021, 10, 323. [CrossRef]

9. Abedkhojasteh, H.; Niyyati, M.; Rahimi, F.; Heidari, M.; Farnia, S.; Rezaeian, M. First Report of Hartmannella keratitis in a Cosmetic Soft Contact Lens Wearer in Iran. Iran. J. Parasitol. 2013, 8, 481-485.

10. Hajialilo, E.; Niyyati, M.; Solaymani, M.; Rezaeian, M. Pathogenic Free-Living Amoebae Isolated From Contact Lenses of Keratitis Patients. Iran. J. Parasitol. 2016, 10, 541-546.

11. Kennedy, S.M.; Devine, P.; Hurley, C.; Ooi, Y.S.; Collum, L.M. Corneal infection associated with Hartmannella vermiformis in contact-lens wearer. Lancet 1995, 346, 637-638. [CrossRef]

12. Aitken, D.; Hay, J.; Kinnear, F.B.; Kirkness, C.M.; Lee, W.R.; Seal, D.V. Amebic Keratitis in a Wearer of Disposable Contact Lenses due to a Mixed Vahlkampfia and Hartmannella Infection. Ophthalmology 1996, 103, 485-494. [CrossRef]

13. Inoue, T.; Asari, S.; Tahara, K.; Hayashi, K.; Kiritoshi, A.; Shimomura, Y. Acanthamoeba keratitis with symbiosis of Hartmannella amoeba. Am. J. Oph-Thalmology 1998, 125, 721-723. [CrossRef]

14. Aimard, L.; Brasseur, P.; Favennec, L.; Perrine, D.; Watt, L.; Brasseur, G. Amebic Keratitis Due to a Mixed Infection with Acanthamoeba and Hartmannella Species. Clin. Infect. Dis. 1998, 26, 187-188. [CrossRef]

15. Alexandrakis, G.; Miller, D.; Huang, A.J. Amebic keratitis due to Vahlkampfia infection following corneal trauma. Arch. Ophthalmol. 1998, 116, 950-951. 
16. Bennett, H.G.B.; Hay, J.; Kirkness, C.M.; Seal, D.V.; Devonshire, P. Antimicrobial management of presumed microbial keratitis: Guidelines for treatment of central and peripheral ulcers. Br. J. Ophthalmol. 1998, 82, 137-145. [CrossRef] [PubMed]

17. Michel, R.; Schmid, E.N.; Böker, T.; Hager, D.G.; Müller, K.-D.; Hoffmann, R.; Seitz, H.M. Vannella sp. harboring Microsporidia-like organisms isolated from the contact lens and inflamed eye of a female keratitis patient. Parasitol. Res. 2000, 86, 514-520. [CrossRef] [PubMed]

18. Scheid, P. Mechanism of intrusion of a microsporidian-like organism into the nucleus of host amoebae (Vannella sp.) isolated from a keratitis patient. Parasitol. Res. 2007, 101, 1097-1102. [CrossRef] [PubMed]

19. Lorenzo-Morales, J.; Martínez-Carretero, E.; Batista, N.; Álvarez-Marín, J.; Bahaya, Y.; Walochnik, J.; Valladares, B. Early diagnosis of amoebic keratitis due to a mixed infection with Acanthamoeba and Hartmannella. Parasitol. Res. 2007, 102, 167-169. [CrossRef]

20. Yera, H.; Zamfir, O.; Bourcier, T.; Viscogliosi, E.; Noël, C.; Dupouy-Camet, J.; Chaumeil, C. The genotypic characterisation of Acanthamoeba isolates from human ocular sam-ples. Br. J. Ophthalmol. 2008, 92, 1139-1141. [CrossRef]

21. Ozkoc, S.; Tuncay, S.; Delibas, S.B.; Akisu, C.; Ozbek, Z.; Durak, I.; Walochnik, J. Identification of Acanthamoeba genotype T4 and Paravahlkampfia sp. from two clinical samples. J. Med. Microbiol. 2008, 57, 392-396. [CrossRef] [PubMed]

22. Niyyati, M.; Lorenzo-Morales, J.; Rezaie, S.; Rahimi, F.; Martín-Navarro, C.M.; Mohebali, M.; Maghsood, A.H.; Farnia, S.; Valladares, B.; Rezaeian, M. First report of a mixed infection due to Acanthamoeba genotype T3 and Vahlkampfia in a cosmetic soft contact lens wearer in Iran. Exp. Parasitol. 2010, 126, 89-90. [CrossRef] [PubMed]

23. Mattana, A.; Pinna, A.; Erre, G.; Fiori, P.L.; Cappuccinelli, P. Biological characterization of free-living amoebae isolated from cases of amoebic keratitis in Sassari. Mappe Parassitol. 2012, 18, 49.

24. Arnalich-Montiel, F.; Lorenzo-Morales, J.; Irigoyen, C.; Morcillo-Laiz, R.; López-Vélez, R.; Muñoz-Negrete, F.; Piñero, J.E.; Valladares, B. Co-isolation of Vahlkampfia and Acanthamoeba in Acanthamoe-ba-Like Keratitis in a Spanish Population. Cornea 2013, 32, 608-614. [CrossRef]

25. Tolba, M.E.M.; Huseein, E.A.M.; Farrag, H.M.M.; Mohamed, H.E.D.; Kobayashi, S.; Suzuki, J.; Ali, T.A.M.; Sugano, S. Allovahlkampfia spelaea Causing Keratitis in Humans. PLoS Negl. Trop. Dis. 2016, 10, e0004841. [CrossRef] [PubMed]

26. Pinna, A.; Porcu, T.; Boscia, F.; Cano, A.; Erre, G.; Mattana, A. Free-Living Amoebae Keratitis. Cornea 2017, 36, 785-790. [CrossRef]

27. Henriquez, F.L.; Mooney, R.; Bandel, T.; Giammarini, E.; Zeroual, M.; Fiori, P.L.; Margarita, V.; Rappelli, P.; Dessì, D. Paradigms of Protist/Bacteria Symbioses Affecting Human Health: Acanthamoeba species and Trichomonas vaginalis. Front. Microbiol. 2021, 11, 616213. [CrossRef]

28. Griffin, J.L. Temperature Tolerance of Pathogenic and Nonpathogenic Free-Living Amoebas. Science 1972, 178, 869-870. [CrossRef]

29. Rayamajhee, B.; Willcox, M.D.; Henriquez, F.L.; Petsoglou, C.; Carnt, N. Acanthamoeba keratitis: An increasingly common infectious disease of the cornea. Lancet Microbe 2021, 2, e345-e346. [CrossRef]

30. Maycock, N.J.R.; Jayaswal, R. Update on Acanthamoeba Keratitis. Cornea 2016, 35, 713-720. [CrossRef]

31. Scottish Intercollegiate Guidelines Network. Algorithm for Classifying Study Design for Questions of Effectiveness. 2021. Available online: https:/ / www.sign.ac.uk/assets/study_design.pdf (accessed on 17 July 2021).

32. University of Strathclyde. Systematic Review Steps. 2020. Available online: https://guides.lib.strath.ac.uk/systematic/steps (accessed on 10 July 2021).

33. The Joanna Briggs Institute. Checklist for Case Control Studies. Available online: https://jbi.global/critical-appraisal-tools (accessed on 1 May 2021).

34. Centre for Evidence Based Management. Critical Appraisal. 2019. Available online: https://cebma.org/resources-and-tools/ what-is-critical-appraisal/ (accessed on 17 July 2021). 